\title{
Reliability-based designs procedure of earth retaining walls in geotechnical engineering
}

Procesos para los diseños por confiabilidad de muros de contención en ingeniería geotécnica

Fecha de entrega: 31 de octubre 2016

Fecha de aceptación: 16 de agosto 2017

\section{Juan C. Viviescas ${ }^{1}$, Juan P. Osorio ${ }^{12}$ and Julio E. Cañón ${ }^{3}$}

\author{
${ }^{1}$ GeoResearch International - GeoR, Escuela Ambiental, Facultad de Ingeniería, Universidad de Antioquia UdeA, Calle 70 No. 52-21, \\ Medellín, Colombia, juan.viviescas@udea.edu.co,juan.osorio@udea.edu.co \\ ${ }^{2}$ School of Civil and Structural Engineering, Dublin Institute of Technology, Bolton Street, Dublin 1, Ireland \\ ${ }^{3}$ Grupo de Investigación en Gestión y Modelación Ambiental GAIA, Facultad de Ingeniería, Universidad de Antioquia, SIU/UdeA, \\ Calle 70 N52-21, Medellín, Colombia, julio.canon@udea.edu.co
}

The design and construction of foundations, retaining structures and slopes are usually based on deterministic formulations that do not allow the distinction between the natural variability and the inherent dispersion in the geotechnical parameters. Due to the inherent variability of the soil properties, there is a growing trend to implement reliability-based designs in geotechnical engineering to reduce design uncertainties by probabilistic methods. The reliability designs require the definition of the probability density functions of the geotechnical properties, as well as knowledge of the spatial variability of soils. This paper identifies the procedures, type of soil investigations, simulations and the most commonly studied areas in geotechnical reliability-based designs. The importance of the correlation length in defining the reduction factors to determine the probabilities of occurrence of events, with Monte Carlo as the most used simulation method in this type of designs, is highlighted. The most commonly studied problems in this regard are related to foundation design and slope stability analyses whereas earth retaining walls and gabion walls are the less studied. Furthermore, no study was found in the determination of the variation of the soil-wall friction nor in the geological influence for this type of structures, which implies a great potential for future research in these areas.

Keywords: earth retaining wall, soil-wall friction, geological influence, probability of failure
El diseño y construcción de cimentaciones, estructuras de contención y taludes se basan generalmente en formulaciones deterministas que no permiten la distinción entre la variabilidad natural y la dispersión inherente de los parámetros geotécnicos. Debido a la variabilidad inherente de las propiedades del suelo, existe una tendencia cada vez mayor en la implementación de diseños basados en la confiabilidad en geotecnia, con el fin de reducir las incertidumbres con métodos probabilísticos. Los diseños por confiabilidad requieren la definición de las funciones de densidad de probabilidad de las propiedades geotécnicas, además de tener el conocimiento de la variabilidad espacial correspondiente a cada tipo de suelo. Este artículo identifica los procedimientos, tipo de investigación del subsuelo, simulaciones y las áreas de estudio más comunes en los diseños geotécnicos basados en la confiabilidad. Se resalta la importancia de la longitud de correlación en la definición de los factores de reducción para determinar las probabilidades de falla y que el método de simulación más utilizado en estos diseños es Monte Carlo. Las áreas de la geotecnia más estudiadas en confiablidad son las de diseño de cimentaciones y análisis de estabilidad de las laderas, mientras que los análisis de muros de contención y muros de gaviones son los menos estudiados. Por otra parte, no se encontraron estudios en la determinación de la variación de la fricción suelo-muro ni en la influencia geológica para este tipo de estructuras, lo que implica un gran potencial para futuras investigaciones.

Palabras clave: muros de contención, fricción suelo muro, influencia geológica, probabilidad de falla

\section{Introduction}

Geotechnical engineering is the area of civil engineering that studies the behaviour of soils and rocks for the design and construction of mainly foundations, retaining walls and slopes. The 
aforementioned designs require the knowledge of the shear strength properties of soils for each of the layers found during ground investigation where the structures are to be located. These properties can be determined with different types of field or laboratory tests, but are commonly used as deterministic values in the different geotechnical models (Phoon and Kulhawy, 1999b). The main problem of the deterministic methods is the inability to assess the probabilities of events for random phenomena that may occur in the soil. Deterministic formulations cannot distinguish between the natural variability and the inherent dispersion of the geotechnical parameters, as these properties are usually obtained by measures of central tendency or are modified subjectively according to field observations and engineering criteria (Phoon and Kulhawy, 1999b). The uncertainties caused by the random behaviour of soil properties and the hypotheses formulated in the interpretation of the parameters may reduce the accuracy of the bearing capacity, earth pressure and slope stability analyses (e.g. Carlsson, 2005). The implementation of statistical models that are able to estimate the uncertainties of the classic methodologies can overcome the lack of accuracy in the deterministic methods.

\section{Previous research}

A variety of works deal with the reliability-based designs in geotechnical engineering, being the most common subject the reliability of slope analysis, with over 200 papers, followed by the reliability of foundations with over 90 papers. Figure 1 shows the amount of papers by subarea.

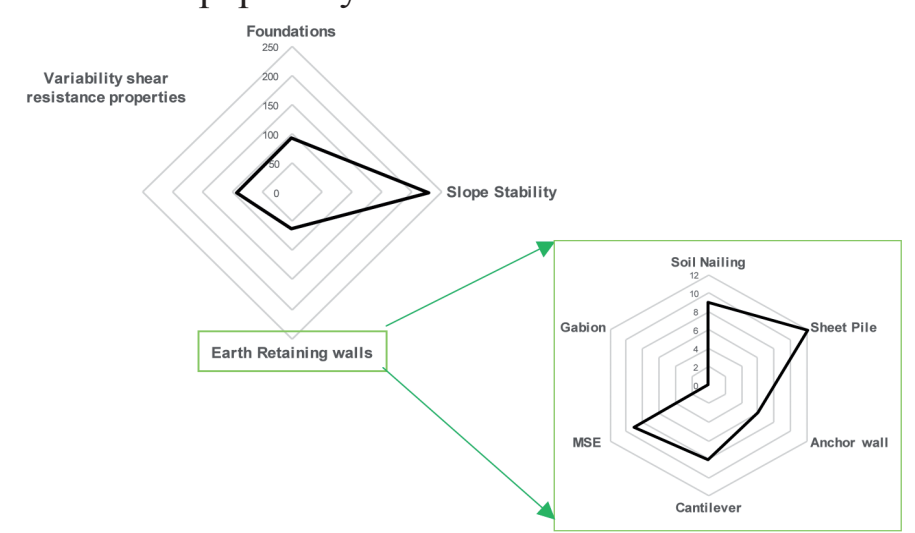

Figure 1: Numbers of papers in reliability based designs in Geotechnics according with the subarea
We made a further refinement with focus on the subject of interest in earth retaining walls. Table 1 presents the state of the art in the reliability design of different type of walls. In the review, pile walls are the most studied structures in reliability-based designs, whilst the anchored walls are the least studied.

Table 1: Summary of reliability based design of earth retaining walls

\begin{tabular}{|c|c|}
\hline $\begin{array}{c}\text { Type of } \\
\text { wall }\end{array}$ & Reference \\
\hline Pile wall & $\begin{array}{l}\text { Basma, 1991a; Cherubini et al., 1992; Goh and } \\
\text { Kulhawy, 2005; GuhaRay and Baidya, 2015; } \\
\text { Koreta et al., 2015; Li et al., 2016; Low and } \\
\text { Phoon, 2015; Papaioannou and Straub, 2010; } \\
\text { Prästings et al., 2016; Sessa and D’Urso, 2013; } \\
\text { Wang, } 2013\end{array}$ \\
\hline $\begin{array}{l}\text { Soil } \\
\text { nailing }\end{array}$ & $\begin{array}{l}\text { Sivakumar Babu and Singh, 2009, 2010, 2011; } \\
\text { Cao et al., 2014; Hui and Zhu, 2013; Lu and } \\
\text { Jiang, 2012; Zhang et al., 2009; Zhao \& An, } \\
2011\end{array}$ \\
\hline Cantilever & $\begin{array}{l}\text { Fenton et al., 2005; Goh et al., 2009; Griffiths } \\
\text { et al., 2008; GuhaRay and Baidya, 2014; Juang } \\
\text { et al., 2013; Liu et al., 2013; Prada et al., 2011; } \\
\text { Zevgolis and Bourdeau, 2010a; Mandali et al., } \\
2011\end{array}$ \\
\hline MSE & $\begin{array}{l}\text { Basheer and Najjar, 1996; Chalermyanont and } \\
\text { Benson, 2004, 2005a, 2005b; Hegazy et al., } \\
\text { 2009; Kim and Salgado, 2012; Miyata and } \\
\text { Bathurst, 2012; Zevgolis and Bourdeau, 2008, } \\
\text { 2010b }\end{array}$ \\
\hline Anchor & $\begin{array}{l}\text { Basha and Sivakumar Babu, 2008; Basma, } \\
\text { 1991b; Chen et al., 2011; Cherubini, 1999; } \\
\text { Low, } 2005\end{array}$ \\
\hline
\end{tabular}

An important feature is the absence of reliability studies in gabion walls. This type of walls is widely used in the world due to their economical and aesthetics characteristics, but they have a variability of dimensions, type of fills and low stiffness. Although this type of walls does not appear in reliability studies, they are commonly found in case history studies and forensic studies. Table 2 shows the quantity of studies carried out on forensic engineering of walls. 
Table 2: Number of papers in forensic engineering of wall failures

\begin{tabular}{|c|c|}
\hline Wall & Number of papers \\
\hline Soil nailing & 42 \\
\hline Sheetpile & 108 \\
\hline Anchor wall & 128 \\
\hline Cantilever & 93 \\
\hline MSE & 57 \\
\hline Gabion & 36 \\
\hline Total & 464 \\
\hline
\end{tabular}

\section{Procedure for reliability-based design}

The reliability-based designs, as the regular deterministic geotechnical ones, require a series of steps to define the different geotechnical properties and field characteristics that affect the probability of failure of geotechnical structures. From 75 references published in the course of four decades, between 1977 and 2016 (Figure 2), the increase of research in this area with time become evident, especially after the year 2000. This increase may be explained due to the advances in computational modelling where more complex statistical analyses were made possible. According with these results, we drafted the following general procedure for reliability-based designs in geotechnical engineering as a common baseline for different subareas of work (Figure 3).

\section{Site investigation}

This task involves undertaking different field test, such as SPT, CPT, DMT or PMT complemented by different laboratory tests, like triaxial and direct shear stress, in order to identify the different soil layers and their mechanical properties. The site investigation not only limits to the definition of soil properties, but may also include the definition of the soil spatial variability. The spatial variability is commonly estimated by the correlation length or scale of fluctuation, originally described by Vanmarcke (1977). This length corresponds to the distance at which the values are significantly correlated, where values separated over this distance will have no correlation (e.g. Fenton and Griffiths, 2008). Some authors work with this

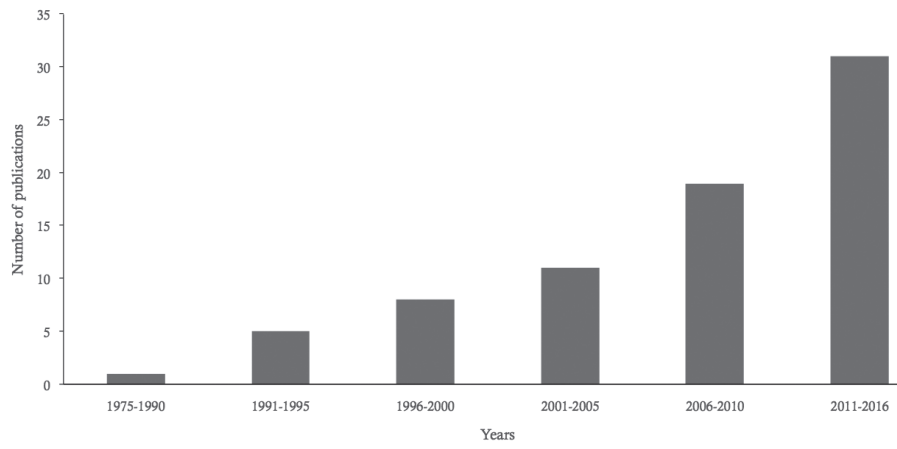

Figure 2: Time line of the evolution in reliability - based designs research works in geotechnical engineering (eje vertical Number of publications)

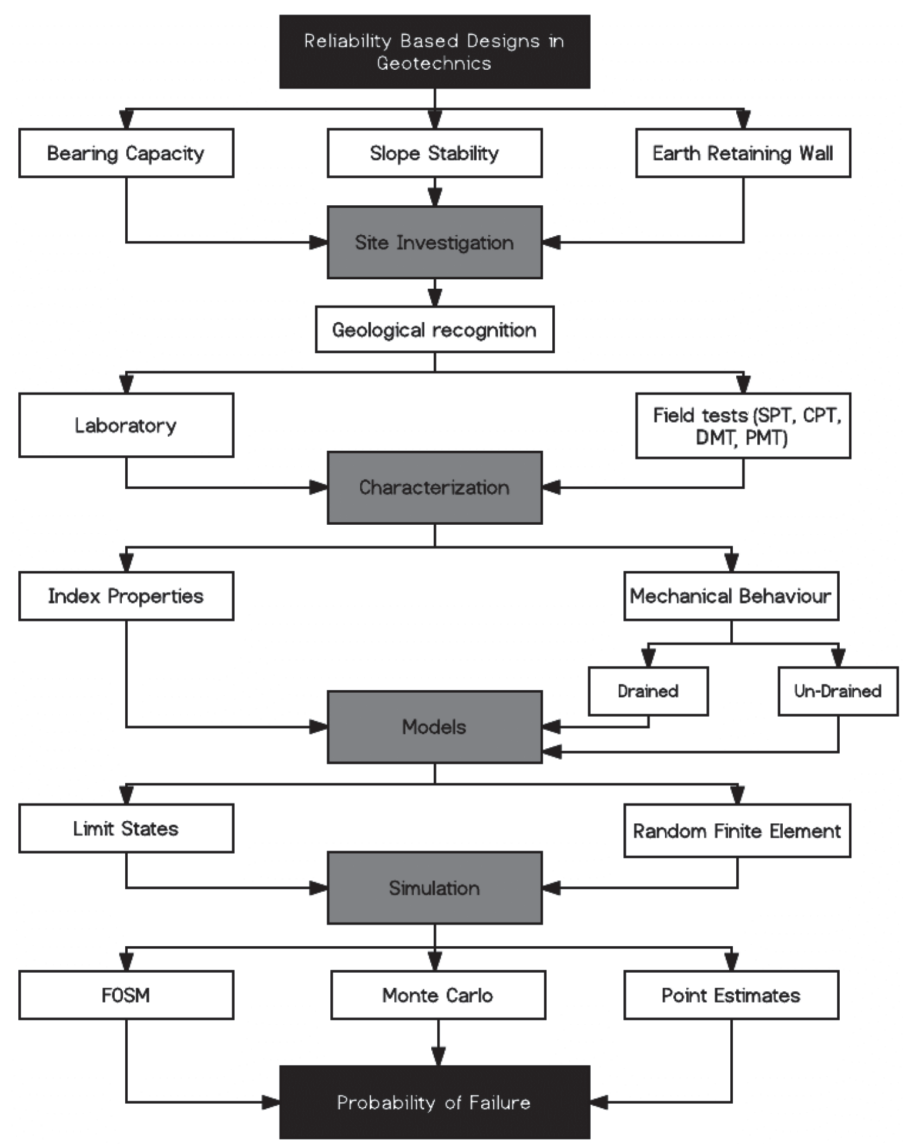

Figure 3: General procedure for reliability-based designs in geotechnical engineering

type of correlation to determine the spatial variability of the soil, like Zou et al. (2015), who used it with cone penetration test results and Cao et al. (2013), who analyzed the effect of the spatial variability in the designs of drilled shafts. The scale of fluctuation 
will determine the influence of the test location in the field and in the determination of the mechanical properties, according to their spatial location, creating a more realistic model of the soil properties (e.g. Fenton and Griffiths, 2010). The spatial variability in geotechnical engineering have been described by a number of authors (Baecher and Christian, 2003; Basarir et al., 2010; Cao et al., 2013; Fenton, 1999; Firouzianbandpey et al., 2014; Gambino and Gilbert, 1999; Jha, 2014; Papaioannou and Straub, 2012).

\section{Soil characterization}

According to Fenton and Griffiths (2010), the ground is a complex engineering material that is difficult to characterize realistically. Its parameters can vary greatly from site to site, evidenced in the coefficient of variation (standard deviation divided by the mean) as illustrated by Phoon and Kulhawy (1999a) and Uzielli et al. (2006). This coefficient of variation $C_{\mathrm{v}}$ is useful when trying to compare the uncertainties of more than one group of data, which differ considerably in the extent of the observation (Montgomery and Runger, 2003). Table 3 and 4 present the values of the coefficient of variation for several properties of different types of soil.

Table 3: Inherent variability of soil properties (Phoon et al., 1995)

\begin{tabular}{|l|c|c|c|c|c|c|}
\hline \multirow{2}{*}{ Property } & \multirow{2}{*}{$\begin{array}{c}\text { Type of } \\
\text { soil }\end{array}$} & \multirow{2}{*}{$\begin{array}{c}\text { Number } \\
\text { of data }\end{array}$} & \multicolumn{2}{|c|}{ Value } & \multicolumn{2}{|c|}{$C_{\mathrm{v}}, \%$} \\
\cline { 4 - 7 } & & range & mean & range & mean \\
\hline$s_{\mathrm{u}}, \mathrm{kPa}$ & Clay & 42 & $8-638$ & 112 & $6-80$ & 32 \\
\hline$\phi^{\prime}, \circ$ & Sand & 7 & $35-41$ & 37.6 & $5-11$ & 9 \\
\hline$\phi^{\prime}, \circ$ & Clay, silt & 12 & $0-33$ & 15.3 & $10-50$ & 21 \\
\hline$\phi^{\prime}, \circ$ & Clay, silt & 9 & $17-41$ & 33.3 & $4-12$ & 9 \\
\hline
\end{tabular}

Due to this uncertainty, the use of response prediction models, which can take into account the spatial variability, are defined as a Probability Density Function PDF of the geotechnical parameters. The probability functions used in the reliability based design identifies the probabilities of occurrence of the soil properties that are susceptible to great change and whose behaviour can only be described by inductive statistical analysis (Baecher and Christian, 2003).
Table 4: Inherent variability of soil properties (Uzielli et al., 2007)

\begin{tabular}{|c|c|c|c|c|}
\hline Test & Property & $\begin{array}{c}\text { Type of } \\
\text { soil }\end{array}$ & $\begin{array}{l}\text { Mean } \\
\text { range }\end{array}$ & $C_{\mathrm{v}}, \%$ \\
\hline \multirow{4}{*}{$\begin{array}{l}\text { Triaxial UC } \\
\text { UU } \\
\text { CIUC } \\
\text { CID }\end{array}$} & $s_{\mathrm{u}}, \mathrm{kPa}$ & Clay & $1-40$ & $20-55$ \\
\hline & $s_{\mathrm{u}}, \mathrm{kPa}$ & Clay & $1-35$ & $10-30$ \\
\hline & $s_{\mathrm{u}}, \mathrm{kPa}$ & Clay & $15-70$ & $20-40$ \\
\hline & $\phi^{\prime},{ }^{\circ}$ & $\begin{array}{c}\text { Clay and } \\
\text { sand }\end{array}$ & $20-40$ & $5-15$ \\
\hline \multirow{3}{*}{ CPT } & $q_{\mathrm{t}}, \mathrm{MPa}$ & Clay & $0.5-2.5$ & $<20$ \\
\hline & \multirow{2}{*}{$q_{\mathrm{c}}, \mathrm{MPa}$} & Clay & $0.5-2.0$ & $20-40$ \\
\hline & & Sand & $0.5-3.0$ & $20-60$ \\
\hline SPT & $N, \mathrm{bpf}$ & $\begin{array}{c}\text { Clay and } \\
\text { sand }\end{array}$ & $10-70$ & $25-50$ \\
\hline \multirow{8}{*}{$\begin{array}{l}\text { Index } \\
\text { properties }\end{array}$} & $w_{\mathrm{n}}, \%$ & $\begin{array}{c}\text { Clay and } \\
\text { silt }\end{array}$ & $13-100$ & $8-30$ \\
\hline & $w_{\mathrm{L}}, \%$ & $\begin{array}{c}\text { Clay and } \\
\text { silt }\end{array}$ & $30-90$ & $6-30$ \\
\hline & $w_{\mathrm{P}}, \%$ & $\begin{array}{c}\text { Clay and } \\
\text { silt }\end{array}$ & $15-25$ & $6-30$ \\
\hline & $I_{\mathrm{P}}, \%$ & $\begin{array}{c}\text { Clay and } \\
\text { silt }\end{array}$ & $10-40$ & - \\
\hline & $I_{\mathrm{L}}, \%$ & $\begin{array}{c}\text { Clay and } \\
\text { silt }\end{array}$ & 10 & - \\
\hline & $\gamma, \mathrm{kN} / \mathrm{m}^{3}$ & $\begin{array}{c}\text { Clay and } \\
\text { silt }\end{array}$ & $13-20$ & $<10$ \\
\hline & \multirow{2}{*}{$D_{R}, \%$} & \multirow{2}{*}{ Sand } & \multirow{2}{*}{$30-70$} & $10-40$ \\
\hline & & & & $50-70$ \\
\hline
\end{tabular}

\section{How to obtain the PDF}

The determination of the PDFs for the drained and undrained shear strength parameters require enough number of laboratory and field tests, which are rarely available to prescribe a full joint distribution (Fenton and Griffiths, 2008). A procedure to define the PDF for the shear strength properties, adapted from Griffiths and Fenton (2008), is described below:

1. If sufficient data are available, select the functions that best fit the histogram of the data.

2. Conduct a goodness of fit test for all the selected PDF's to evaluate how well the fitted distribution represents the true underlying distribution of data. Commonly used tests are Chi-Square, Kolmogorov-Smirnov and Anderson-Darling tests.

3. After defining the PDF's, ensure that the distribution represents the soil property realistically. For example, some variables cannot 
have negative values (e.g. modulus of elasticity or friction angle); nonetheless, some functions, such as the normal distribution, may present negative tails that can affect the results. Distributions with negative tails are allowed, as long as the probability of occurrence of these values is very low.

4. Compare the results with distributions available in the literature, especially when making assumptions or using a database.

5. If there is more than one possible PDF, choose the simplest one.

6. Estimate the final PDF parameters by the Method of Moments or Maximum likelihood.

The normal or lognormal probability functions can usually represent random processes that occur in the soil. However, under specific conditions, different functions are applicable in order to adjust the sampling distributions more accurately as is shown in Table 5. Normally, the grain size distribution is used to explain the parameters, distribution and behaviour of soil properties. However, the influence of the geological origin in the soil properties has not yet been considered. The geological origin not only generates a particular grain size distribution, but it can correlate to the state of weathering, type of formation (residual or transported) and to the previous state of stresses and how these factors can affect the variability of the geotechnical parameters.

\section{Influence of the geological origin}

The geological environment not only determines the type of site investigation to conduct on any site, but it can also explain the discrepancies usually observed in the mechanical behaviour of different types of soils. Mud or debris flows, for instance, behave in very different manners when compared to residual soils. The former, for example, is comprised by rock fragments with different states of weathering embedded in a homogenous matrix, and this type of formation affects the results from the different field test that can be performed during ground exploration. These tests might evaluate the resistance of a particular rock fragment that do not represent the behaviour of the soil mass as shown in Figure 4.

On the other hand, geotechnical engineering is less developed when it comes to analyze residual soils, since it has advanced mostly in sedimentary formations (Mitchell and Soga, 2005; Wesley, 2009, 2011). However, residual soils tend to have a similar grain size distribution with the presence of

Table 5: Probability functions used in reliability designs in geotechnics (Mattos and Viviescas, 2015)

\begin{tabular}{|c|c|c|c|c|}
\hline Friction angle $\phi '$ & Cohesion $c$ & Unit weight $\gamma$ & Surcharge $R$ & Reference \\
\hline $\begin{array}{l}\text { Normal, log normal, Beta, } \\
\text { Gamma and Uniform }\end{array}$ & $\mathrm{X}$ & $\begin{array}{l}\text { Normal, lognormal, } \\
\text { Beta and Gamma }\end{array}$ & $\mathrm{x}$ & $\begin{array}{l}\text { Baecher and Christian } \\
(2003)\end{array}$ \\
\hline Normal & Normal & Normal & $\mathrm{x}$ & $\begin{array}{l}\text { Sivakumar Babu and } \\
\text { Srivastava (2007) }\end{array}$ \\
\hline Lognormal & $\mathrm{x}$ & $\mathrm{x}$ & $\mathrm{x}$ & Cherubini et al. (2007) \\
\hline Normal & $\mathrm{x}$ & Normal & $\mathrm{x}$ & Uzielli et al. (2007) \\
\hline Normal y Lognormal & $\begin{array}{c}\text { Normal and } \\
\text { lognormal }\end{array}$ & Normal and lognormal & $\begin{array}{l}\text { Gamma and } \\
\text { Weibull }\end{array}$ & Phoon (2008) \\
\hline $\mathrm{X}$ & Beta & $\mathrm{x}$ & $\mathrm{x}$ & $\begin{array}{l}\text { Qingnian and Yuzhou } \\
(2011)\end{array}$ \\
\hline Normal & Lognormal & Normal & $\mathrm{x}$ & Prada et al. (2011) \\
\hline Beta & $\mathrm{x}$ & Normal & $\mathrm{x}$ & $\begin{array}{l}\text { Papaioannou and Straub } \\
(2012)\end{array}$ \\
\hline $\mathrm{X}$ & Lognormal & Lognormal & Gamma & Fan and Liang (2013) \\
\hline Normal & Normal & Normal & $\mathrm{x}$ & $\mathrm{Wu}(2013)$ \\
\hline
\end{tabular}


some randomly distributed, partly weathered, rock fragment. Nonetheless, depending on the type of formation and the influence of the weathering with depth, the soil properties may have different scale of fluctuations that can make the definition of the soil parameters difficult. Therefore, the integration of geology with reliability-based designs, will reduce to some extent the gap between the uncertainty of the designs and the field behaviour of the geo-structures.
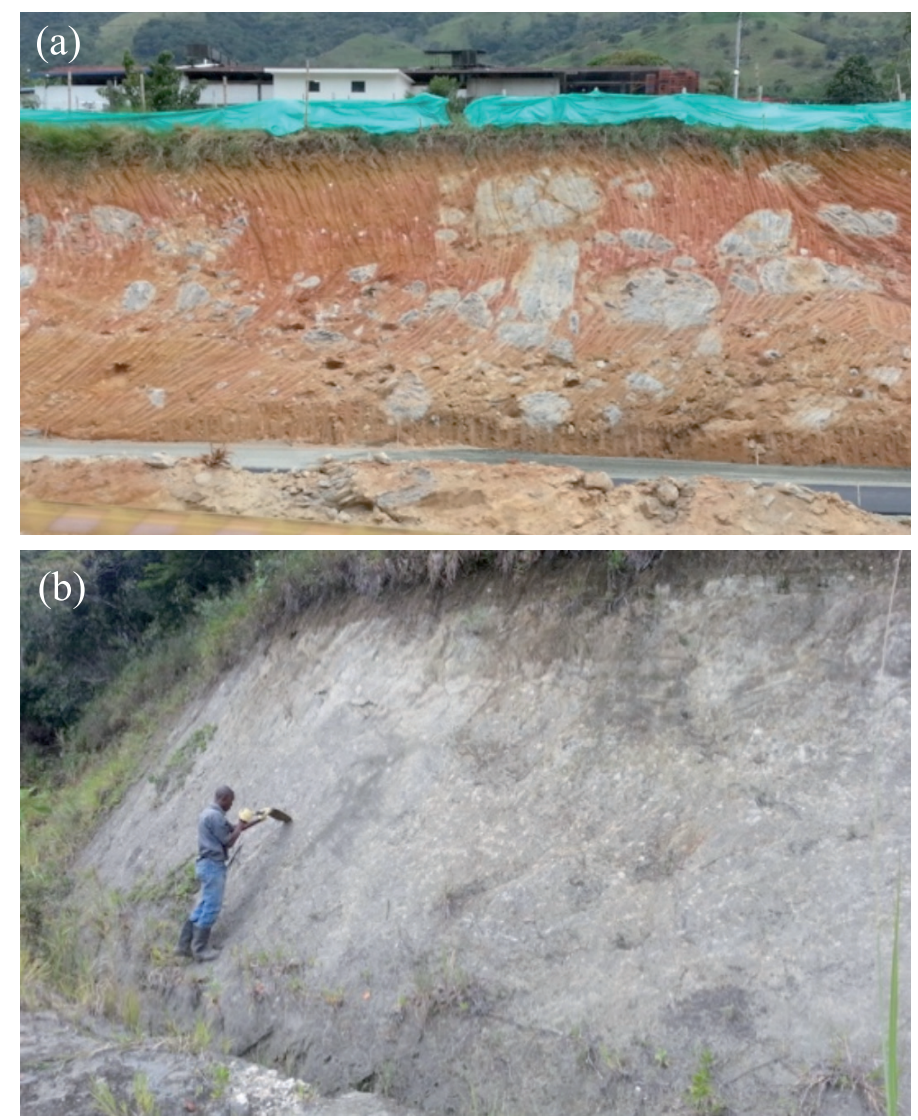

Figure 4: a) Mud/debris flow and b) residual soils characteristics

\section{Geotechnical models}

The most commonly used models in geotechnics are the limit state (failure or serviceability) and finite elements models. The former is based on the classical theory of failure and elastic deformations in order to define the bearing capacity of foundations, slopes stability and earth pressures. The latter is based on stress-strain equations discretized in small nodes (Smith et al., 2013). The finite elements model is widely used in geotechnical engineering, because it determines the failure by the weak areas and not by a preset area (e.g. Griffiths and Lane, 1999). Because of the uncertainty of the parameters represented by the PDF, Random Finite Element Models RFEM arise, allowing the determination of fault conditions and the probability of success in the finite element method through a simulation method (Griffiths and Fenton, 1993).

\section{Simulation methods}

Several statistical methods involve various numerical analysis techniques for assessing the reliability of the geotechnical designs under a probabilistic approach. The most used simulation methods are the Method of First Order Second Moment FOSM, method of point estimates (Rosenblueth, 1975) and Monte Carlo method (e.g. Hidalgo and Pacheco, 2011). According to Lacasse and Nadim (1998), the applicability of the Monte Carlo method in geotechnical engineering is widely known for its conceptual simplicity compared to other methods. As shown in Figure 5, the use of Monte Carlo more than doubles the use of other methods in the specialized literature.

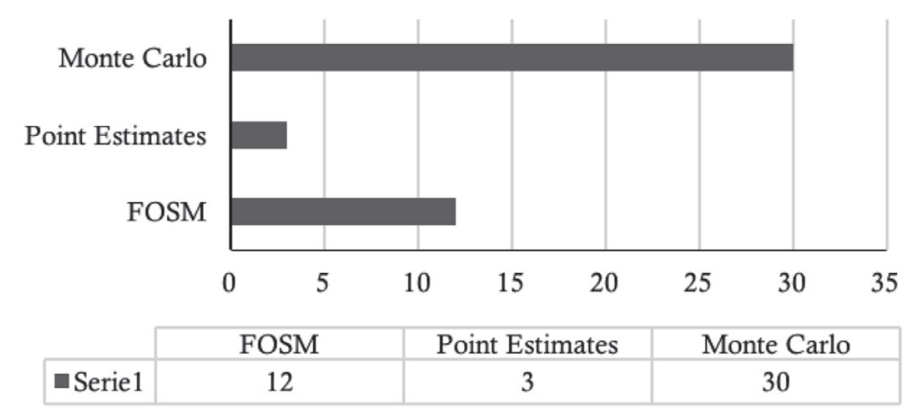

Figure 5: Simulation methods used on different papers in reliability-based designs in Geotechnics

Considering the above, we summarize a procedure for the reliability-based designs in the flowchart of Figure 6. The flowchart covers the type of investigation, the definition of a PDF that adequately represents soil properties and the analysis of the model results, in order to obtain the best estimate of the probability of failure. 


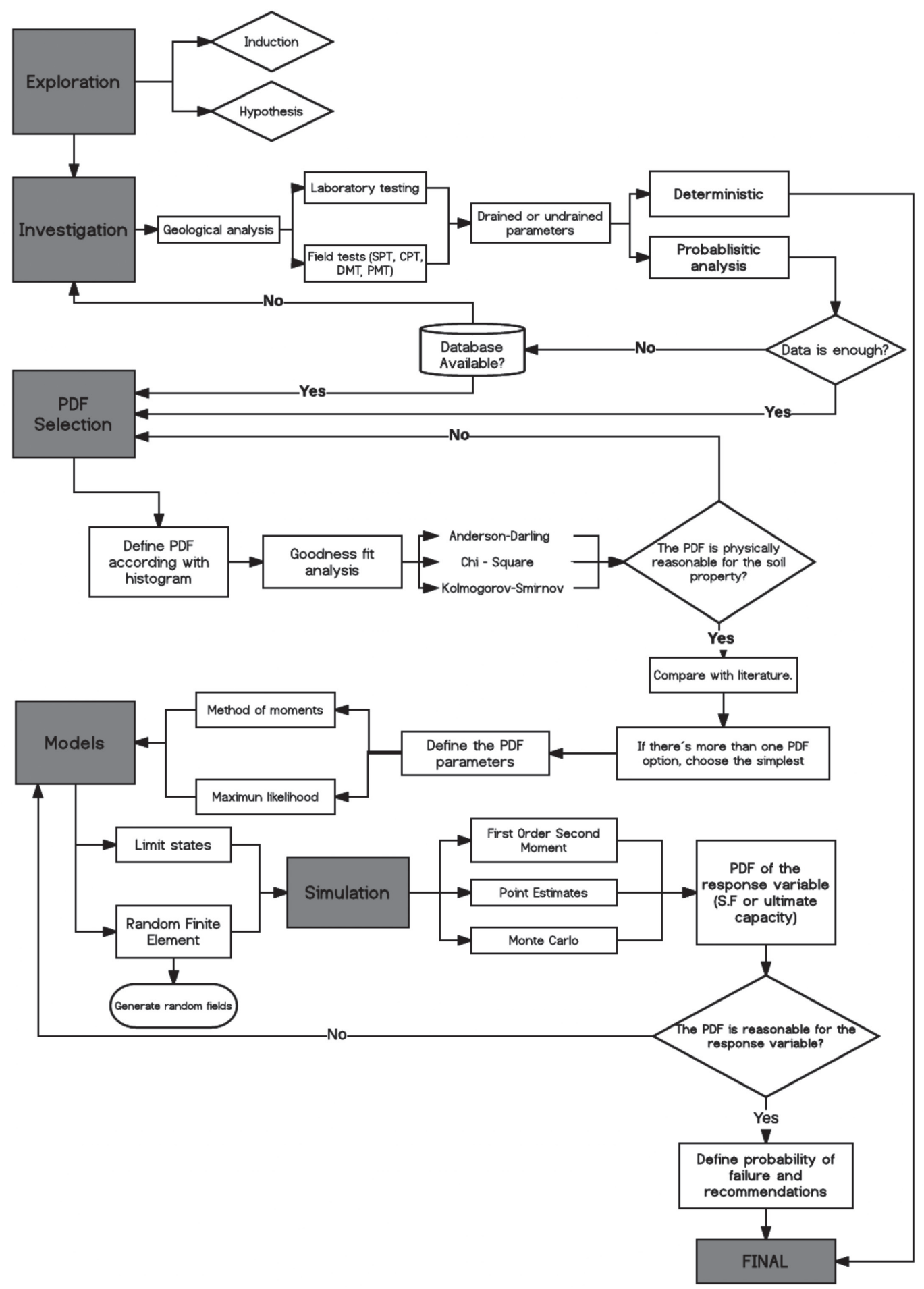

Figure 6: Flowchart to define the probability of failure in geotechnical engineering

\section{Conclusions}

It was found that pile walls are the most commonly studied retaining structures in reliability-based designs in geotechnical engineering. This can be explained by the fact that this type of structures are more frequently implemented compared to other type of walls. However, economy and new needs to find faster solutions to the earth retaining structures, it is expected that the anchor walls will take more ground in the reliability based designs. On the other hand, there is an absence of reliability studies in Gabion walls, which may be explained by the variability of the 
dimensions, type of fills and low stiffness of this type of walls, which make them highly complex to study and a less desirable choice for reliability-designs, despite its widespread use in several countries. There is also a lack of studies regarding the determination of the probability density functions of the soil-wall friction. This is an important variable in defining the stability of retaining structures. Soil-wall friction is commonly defined deterministically as a fraction of the friction angle, regardless of the contact material and the geological origin of the soil.

Studies that relate the geotechnical variables and models with the geological origin are not yet available. The consideration of the relationship between geological origin and mechanical properties in reliability-based designs will reduce uncertainties among the designs and better represent the real behaviour of geo-structures.

The definition of the PDF is among the most difficult tasks in the reliability-based designs, as it requires a large amount of data or access to reliable databases on similar soils, something commonly non-existent. The definition of these functions must also consider the shape of the function and the value of the parameters, because if these functions present a high content of negative values, a large amount of nonreal values will arise in the models. Monte Carlo is the most implemented simulation method due to its conceptual simplicity compared to other methods. This has led to its adoption in different commercial and non-commercial software for geotechnical designs. Finally, a reliability-design procedure is proposed, which aims at generating the best representation of each variable and model from the start of the project and propending to define the probability of failure more accurately. Erroneous estimates of the probability of failure may lead to accept high-risk structures or to reject safe structures, affecting the economy and safety of different types of geotechnical structures.

\section{Acknowledgement}

The authors would like to acknowledge the financial support provided by the Administrative Department of Science, Technology and Innovation of Colombia - Colciencias, under the National Doctoral Grant Scheme No. 727 of 2015.

\section{References}

Baecher, G.B. and Christian, J.T. (2003). Reliability and statistics in geotechnical Engineering. John Wiley and Sons

Basarir, H., Kumral, M., Karpuz, C. and Tutluoglu, L. (2010). Geostatistical modeling of spatial variability of SPT data for a borax stockpile site. Engineering Geology, 114(3), 154-163

Basha, B.M. and Sivakumar Babu, G.L. (2008). Target reliability based design optimization of anchored cantilever sheet pile walls. Canadian Geotechnical Journal 45(4), 535-548

Basheer, I. and Najjar, Y. (1996). Reliability-based design of reinforced earth retaining walls. Transportation Research Record 1526(1), 64-78

Basma, A.A. (1991a). Reliability-based design of sheet pile structures. Reliability Engineering \& System Safety 33(2), 215230

Basma, A.A. (1991b). Safety and reliability of anchored bulkhead walls. Structural Safety 10(4), 283-295

Cao, J., Liu, T. and Liu, H.M. (2014). Soil nailing reliability optimization design of foundation pit based on response surface method. Applied Mechanics and Materials 556, 4655-4659

Cao, Z., Wang, J. and Wang, Y. (2013). Effects of spatial variability on reliability-based design of drilled shafts. Foundation Engineering in the Face of Uncertainty: Honoring Fred H. Kulhawy, Geotechnical Special Publication 229, 602616

Carlsson, M. (2005). Management of geotechnical risks in infrastructure projects: An introductory study. $\mathrm{PhD}$ thesis, Royal Institute of Technology

Chalermyanont, T. and Benson, C.H. (2004). Reliabilitybased design for internal stability of mechanically stabilized earth walls. Journal of Geotechnical and Geoenvironmental Engineering 130(2), 163-173

Chalermyanont, T. and Benson, C.H. (2005a). Method to estimate the system probability of failure of Mechanically Stabilized Earth (MSE) walls. GeoFrontiers Congress 2005, Slopes and Retaining Structures Under Seismic and Static Conditions, Austin, 2735-2749 
Chalermyanont, T. and Benson, C. H. (2005b). Reliability-based design for external stability of mechanically stabilized earth walls. International Journal of Geomechanics 5(3), 196-205

Chen, J.B., Hu, Q. and Zhou, Y.W. (2011). Research of controlling for pile-anchor joint supporting structure on deformation of deep foundation pits. Advanced Materials Research 261, 1809-1813

Cherubini, C. (1999). Probabilistic approach to the design of anchored sheet pile walls. Computers and Geotechnics 26(3), 309-330

Cherubini, C., Garrasi, A. and Petrolla, C. (1992). The reliability of an anchored sheet-pile wall embedded in a cohesionless soil. Canadian Geotechnical Journal 29(3), 426-435

Cherubini, C., Vessia, G. and Pula, W. (2007). Statistical soil characterization of Italian sites for reliability analyses. Characterization and Engineering Properties of Natural Soils, Singapore, vol. 4, 2681-2706

Fan, H. and Liang, R. (2013). Reliability-based design of axially loaded drilled shafts using Monte Carlo method. International Journal for Numerical and Analytical Methods in Geomechanics 37(14), 2223-2238

Fenton, G.A. (1999). Random field modeling of CPT data. Journal of Geotechnical and Geoenvironmental Engineering 125(6), 486-498

Fenton, G.A. and Griffiths, D.V. (2008). Risk assessment in geotechnical engineering. John Wiley \& Sons

Fenton, G.A., Griffiths, D.V. and Williams, M.B. (2005). Reliability of traditional retaining wall design. Géotechnique 55(1), 55-62

Fenton, G.A. and Griffiths, D.V. (2010). Reliability-based geotechnical engineering. GeoFlorida Conference, Orlando, $1-40$

Firouzianbandpey, S., Griffiths, D.V., Ibsen, L.B. and Andersen, L.V. (2014). Spatial correlation length of normalized cone data in sand: case study in the north of Denmark. Canadian Geotechnical Journal 51(8), 844-857

Gambino, S.J. and Gilbert, R.B. (1999). Modeling spatial variability in pile capacity for reliability-based design. Analysis, Design, Construction, and Testing of Deep Foundations, Geotechnical Special Publication 88, 135-149
Goh, A.T.C. and Kulhawy, F.H. (2005). Reliability assessment of serviceability performance of braced retaining walls using a neural network approach. International Journal for Numerical and Analytical Methods in Geomechanics 29(6), 627-642

Goh, A.T., Phoon, K.K. and Kulhawy, F.H. (2009). Reliability analysis of partial safety factor design method for cantilever retaining walls in granular soils. Journal of Geotechnical and Geoenvironmental Engineering 135(5), 616-622

Griffiths, D.V. and Fenton, G.A. (1993). Seepage beneath water retaining structures founded on spatially random soil. Géotechnique 43(4), 577-587

Griffiths, D.V., Fenton, G.A. and Ziemann, H.R. (2008). Reliability of passive earth pressure. Georisk: Assessment and Management of Risk for Engineered Systems and Geohazards 2(2), 113-121

Griffiths, D.V. and Lane, P.A. (1999). Slope stability analysis by finite elements. Géotechnique 49(3), 387-403

GuhaRay, A. and Baidya, D.K. (2014). Partial safety factors for retaining walls and slopes: A reliability based approach. Geomechanics and Engineering 6(2), 99-115

GuhaRay, A. and Baidya, D.K. (2015). Reliability-based analysis of cantilever sheet pile walls backfilled with different soil types using the finite-element approach. International Journal of Geomechanics 15(6), 6015001-11

Hegazy, Y.A., Withiam, J.L., Gladstone, R.A. and Anderson, P.L. (2009). LRFD pullout resistance calibration of coherent gravity method for steel reinforced MSE walls. 17th International Conference on Soil Mechanics and Geotechnical Engineering, Alexandria, vol. 2, 1481-1484

Hidalgo, C.A. y Pacheco, A. (2011). Herramientas para análisis por confiabilidad en geotecnia: La teoría. Revista de Ingeniería de La Universidad de Medellín 10(18), 69-77

Hui, C.Y. and Zhu, Y.P. (2013). Analysis of the reliability of soil nailing supporting structure. Applied Mechanics and Materials 353, 540-543

Jha, S.K. (2014). Effect of spatial variability of soil properties on slope reliability using random finite element and first order second moment methods. Indian Geotechnical Journal 45(2), $145-155$ 
Juang, C.H., Liu, Z. and Atamturktur, H.S. (2013). Reliabilitybased robust geotechnical design of retaining walls. Sound Geotechnical Research to Practice: Honoring Robert D. Holtz II, Geotechnical Special Publication 230, 514-524

Kim, D. and Salgado, R. (2012). Load and resistance factors for external stability checks of mechanically stabilized earth walls. Journal of Geotechnical and Geoenvironmental Engineering 138(3), 241-251

Koreta, O., Myftaraga, E. and Tanku, E. (2015). Probabilistic analysis of a cantilever sheet pile wall penetrating clay. XVI European Conference on Soil Mechanics and Geotechnical Engineering, Edimburgh, Vol. 7, 3965-3970

Lacasse, S. and Nadim, F. (1998). Risk and reliability in geotechnical engineering. $4^{\text {th }}$ International Conference on Case Histories in Geotechnical Engineering, St. Louis, 1172-1192

Li, D.Q., Shao, K.B., Cao, Z.J., Tang, X.S. and Phoon, K.K. (2016). A generalized surrogate response aided-subset simulation approach for efficient geotechnical reliability-based design. Computers and Geotechnics 74, 88-101

Liu, Z., Juang, C.H. and Atamturktur, S. (2013). Confidence level-based robust design of cantilever retaining walls in sand. Computers and Geotechnics 52, 16-27

Low, B.K. (2005). Probabilistic design of anchored sheet pile wall. 16th International Conference on Soil Mechanics and Geotechnical Engineering, Osaka, Vol. 4, 2825-2828

Low, B.K. and Phoon, K.K. (2015). Reliability-based design and its complementary role to Eurocode 7 design approach. Computers and Geotechnics 65, 30-44

Lu, R.L. and Jiang, Q.H. (2012). Reinforcement scheme and numerical simulation for sequential excavation of the deep foundation pit. Applied Mechanics and Materials 204, 359-365

Mandali, A.K., Sujith, M.S., Rao, B.N. and Maganti, J. (2011). Reliability analysis of counterfort retaining walls. Electronic Journal of Structural Engineering 11(1), 42-56

Mattos, A.J. and Viviescas, J.C. (2015). Diseño por confiabilidad de zapatas sobre suelos arenosos utilizando el método de Monte Carlo. Bachelor of Engineering thesis, Universidad de Antioquia.

Mitchell, J.K. and Soga, K. (2005). Fundamentals of soil behavior. John Wiley \& Sons
Miyata, Y. and Bathurst, R.J. (2012). Reliability analysis of soilgeogrid pullout models in Japan. Soils and Foundations 52(4), $620-633$

Montgomery, D.C. and Runger, G.C. (2003). Applied Statistics and Probability for Engineers. John Wiley \& Sons

Papaioannou, I. and Straub, D. (2012). Reliability updating in geotechnical engineering including spatial variability of soil. Computers and Geotechnics 42, 44-51

Papaioannou, I. and Straub, D. (2010). Geotechnical reliability updating using stochastic FEM. Reliability and Optimization of Structural Systems, Munich, 155-162

Phoon, K.K. (2008). Reliability-based design in geotechnical engineering: computations and applications. CRC Press

Phoon, K.K. and Kulhawy, F.H. (1999a). Characterization of geotechnical variability. Canadian Geotechnical Journal 36(4), 612-624

Phoon, K.K. and Kulhawy, F.H. (1999b). Evaluation of geotechnical property variability. Canadian Geotechnical Journal 36(4), 625-639

Phoon, K., Kulhawy, F.H. and Grigoriu, M.D. (1995). Reliabilitybased design of foundations for transmission line structures. Report TR-105000, Palo Alto

Prada, F., Ramos, A., Solaque, D. and Caicedo, B. (2011). Reliability applied to the geotechnical design of a retaining wall. Obras y Proyectos 9, 49-58 (in Spanish)

Prästings, A., Larsson, S. and Müller, R. (2016). Multivariate approach in reliability-based design of a sheet pile wall. Transportation Geotechnics 7, 1-12

Qingnian, Y. and Yuzhou, S. (2011). The fitting method of parameter distributions in geotechnical engineering under small sample. 2nd International Conference on Artificial Intelligence, Management Science and Electronic Commerce, IEEE, 73667369

Rosenblueth, E. (1975). Point estimates for probability moments. Proceedings of the National Academy of Sciences 72(10), 38123814

Sessa, S. and D’Urso, M.G. (2013). Employment of Bayesian networks for risk assessment of excavation processes in dense urban areas. 11th International Conference on Structural Safety and Reliability, 3163-3169 
Sivakumar Babu, G.L. and Singh, V.P. (2011). Reliabilitybased load and resistance factors for soil-nail walls. Canadian Geotechnical Journal 48(6), 915-930

Sivakumar Babu, G.L. and Singh, V.P. (2010). Reliability analyses of a prototype soil nail wall using regression models. Geomechanics and Engineering 2(2), 71-88

Sivakumar Babu, G.L. and Singh, V.P. (2009). Reliability analysis of soil nail walls. Georisk: Assessment and Management of Risk for Engineered Systems and Geohazards 3(1), 44-54

Sivakumar Babu, G.L. and Srivastava, A. (2007). Reliability analysis of allowable pressure on shallow foundation using response surface method. Computers and Geotechnics 34(3), 187-194

Smith, I.M., Griffiths, D.V. and Margetts, L. (2013). Programming the finite element method. John Wiley \& Sons

Uzielli, M., Lacasse, S., Nadim, F. and Phoon, K.K. (2006). Soil variability analysis for geotechnical practice. Characterisation and Engineering Properties of Natural Soils, vol. 3, 1653-1752 Vanmarcke, E.H. (1977). Probabilistic modeling of soil profiles. Journal of the Geotechnical Engineering Division 103(11), 1227-1246

Wang, Y. (2013). MCS-based probabilistic design of embedded sheet pile walls. Georisk: Assessment and Management of Risk for Engineered Systems and Geohazards 7(3), 151-162

Wesley, L. (2011). Stability of slopes in residual soils. Obras y Proyectos 10, 47-61
Wesley, L. (2009). Behaviour and geotechnical properties of residual soils and allophane clays. Obras y Proyectos 6, 33-50

Wu, X.Z. (2013). Trivariate analysis of soil ranking-correlated characteristics and its application to probabilistic stability assessments in geotechnical engineering problems. Soils and Foundations 53(4), 540-556

Zevgolis, I.E. and Bourdeau, P.L. (2010a). Probabilistic analysis of retaining walls. Computers and Geotechnics 37(3), 359-373

Zevgolis, I.E. and Bourdeau, P.L. (2010b). System reliability analysis of the external stability of reinforced soil structures. Georisk: Assessment and Management of Risk for Engineered Systems and Geohazards 4(3), 148-156

Zevgolis, I.E. and Bourdeau, P.L. (2008). Stochastic modeling of redundancy in mechanically stabilized earth (MSE) walls. GeoCongress 2008, New Orleans, 1179-1186

Zhang, L.L., Zhang, L.M. and Tang, W.H. (2009). Uncertainties of field pullout resistance of soil nails. Journal of Geotechnical and Geoenvironmental Engineering 135(7), 966-972

Zhao, Y.L. and An, W.G. (2011). Reliability-based stability analysis of a foundation pit supported by composite soil nailing. Journal of Harbin Engineering University 32(10), 1300-1304

Zou, H.F., Cai, G.J., Liu, S.Y. and Lin, J. (2015). Research on modeling inherent spatial variability of piezocone penetration test cone tip resistance based on geostatistics. Rock and Soil Mechanics 36(S1), 403-407 